\title{
Improving elementary school motivation in learning science
}

\author{
Ice Muniwastia ${ }^{1}$,Yanti Fitriaice Muniwastia ${ }^{2}$, Yanti Fitria ${ }^{3}$, Ardipal ${ }^{4}$ \\ 1234 Universitas Negeri Padang, Padang - Indonesia, (icemuniwastia@yahoo.come)
}

\begin{abstract}
This article was written based on the results of classroom action research on students learning motivation elementary school. This study aims to describe the improvement of learning motivation of the fourth grade students of the elementary school by applying the model of Problem Based Learning.The research model used Classroom Action Research methods that take place in two research cycles. Each cycle consists of planning, execution, observation, and reflection.The data analysis is a combination of qualitative and quantitative. The data analysis is a combination of qualitative and quantitative. Subjects in this study were 32 students.The results showed that the application of Problem Based Learning model proved to increase the motivation of learning grade four elementary school students.
\end{abstract}

Keywords: learning motivation, problem based learning.

\section{Introduction}

Science subjects (Natural Sciences, SCIENCE) is the main subject that should be implemented in elementary school (SD), which examines the natural environment as well as the symptoms in daily life. The students' understanding of the environment is accompanied by their ability to apply science in life so that education has the effort to create a literate citizen especially about science (Fitria, 2017: 30). Science is a kind of learning subject that not only teach about the form of facts but also a process of discovery. Science is one of the subjects that must be taught and studied in elementary school from class I to class VI. Science is literally also a subject that can train and provide students with critical and objective thinking opportunities. It aims to make students able to analyze what they learn, carefully and thoroughly in making decisions, and able to reason the relationship of an event or phenomenon of nature with each other so as to create a critical scientific thinking early on. Fitria (2017:30) states: "Experiences in Science are capable of changing the way thinking and shaping students' scholarly attitudes."

Depdiknas (2006: 488) states that, "Science is concerned with a systematic way of finding out about nature so that science is not just the mastery of a collection of knowledge in the form of facts, concepts or principles but also a process of discovery." Susanto (2013: 166) points out that, "Science Learning in Primary Schools is still largely being implemented conventionally, teachers have not fully implemented active and creative learning in involving students and have not used various learning models that vary based on lesson characters." 
Science learning conducted in elementary school should make students highly motivated to learn because the subject matter of science is a material that is close to student life and raises great curiosity in students. The science lesson should be done to make an invention,this is in line with Fitria's opinion (2017: 35), states that: "Science learning is related to how to find out about nature systematically, so that not only the mastery of knowledge in the form of the results but also a process discovery ",thus motivating students to think creatively and critically to the problems around him. Therefore, in science learning, teachers should provide direct experience to the students so that the learning that occurs will be meaningful for the students, increasing the students 'motivation to learn and stimulate students' curiosity to explore the material being studied.

The author's experience in implementing the learning, as a teacher can observe students in three groups of high-ability groups, medium-ability groups, and low-ability groups. If the teacher gives the task, generally the low and moderate students still have difficulties. This is because the student's ability to understand the lesson learned is not optimal. In the process of learning, teachers still emphasize the concept of learning based on the material contained in the book, and not maximally in utilizing the environment as a source of learning. Lessons learned have not started from the problems that exist in the student environment, so that lessons that take place less attention of students. This condition shows the low motivation of students in following the learning. When learning takes place the students are not focused and prefer to talk with friends rather than follow the lesson. If students find a problem in science learning, the student has not been able to solve it scientifically because he does not understand what to do. In the implementation of the learning process, the teacher only explains the material to the students, whereas students should experiment to develop their thinking ability. Because students do not understand the lessons they experience, the students' motivation to follow the lesson becomes less.

The result of observation of researcher to motivation to learn science attached on result of preliminary study of scoring of motivation questionnaire page 116 shows from 32 student, 17 students have less motivation qualification to follow science lesson. Motivation enough 11 people and only 4 people have good learning motivation. It can be concluded that the learning motivation of fourth graders of SDN 07 Belakang Balok on average is still less and this indirectly affect the student learning outcomes.

The learning process of science especially in SDN 07 Belakang Balok at class IV, used to focus on the teacher (teacher centre) and often explains the material contained in the textbook without relating the material to the daily problems of the students in accordance with the material. This is because of the lack of knowledge of teachers about the use of models in science learning, so that in learning process the teacher is more dominant using lecture methods, thus teacher-centered learning resulted in: (1) students less active in the learning process, (2) they also less able to realize with the problem that is happening, (3) students' reasoning power in solving problems can't be developed. Motivation is also closely related to student learning outcomes, from 32 students, only 11 students who completed the competency, while 21 students still under the target. Therefore, the achievement of the first semester exam result in the science lesson, not all the students have reached the Minimum Criterion (KKM) that is 75 , while the average score of science learning outcomes in grade IV SDN 07 Belakang Balok only 69.

One of the problem-oriented learning model that alleged able to develop students' thinking ability is the Problem Based Learning (PBL) models. Kunandar (2009: 354) states, "Problem Based Learning Modelis a learning model that uses real-world problems as a context for students to learn critical thinking and problem-solving skills, and to acquire essential knowledge and concepts from subject matter". Based on Kunandar's opinion it can be seen that in PBL learning is implemented using realworld problems that lead students to be able to think critically and skillfully in solving problems so that students find the essential concepts of learning materials. PBL is a learning model that can help to optimize students' thinking ability through group work or systematic process, so that students can 
empower, sharpen, test, and develop their thinking ability continuously. The author uses this PBL model because in the learning begins from the existing problems in the student environment that leads students to work with their group to find solutions to the problems given. Learning with PBL models can create a student-centered learning(Students Centered)that promotes the learning process into a better level. This research was conducted to reveal data and information about the improvement of motivation and student learning outcomes with the application of PBL approach in learning.

According to Mc. Donal (dalam Hamalik, 2008: 158), "motivation is an energy change within the person characterized by affective arousal and anticipatory goal reaction". Donal (in Hamalik, 2008: 158), "motivation is an energy change within the person characterized by affective arousal and antic science try goal reaction". That is, motivation is a change of energy in a person characterized by the emergence of feelings and reactions to achieve goals. Sardiman (2007: 75) suggests that, "motivation is a series of attempts to provide certain conditions, so that one wants and wants to do something, and if he does not like it, it will seek to nullify or circumvent those feelings of dislike". Motivation in learning has certain types. Hamalik (2008: 162) argues that "mainly, motivation can be divided into two types: (1) intrinsic motivation, and (2) extrinsic motivation". Based on the opinions expressed by the experts above, it can be concluded that the motivation is the energy contained in a person to conduct a series of efforts to do something in achieving goals.

The learning model Problem Based Learning(PBL) is a learning model that uses the problems in the learning process. Students are asked to identify problems, whether they are real or examine a case. Critically, students think and cooperate with members of their group to find solutions to the problems they find. Ronis (2009: 7) argued that, "Problem-based learning (PBL) is based on the idea that individuals fashion their understanding largely through what the experience". It means thatproblem based learning is based on the idea that individual understanding is largely shown through experience. PBL as one of the learning model of course has its own understanding. This understanding is given in order to be clearly understood about the concept of PBL that will be used in learning. According to Nurhadi (2003: 55), "PBL is a learning model that uses problems as a context for students to learn about critical thinking and problem-solving skills, and to acquire essential knowledge and concepts from the subject matter". Then Duch (in Wianti, 2008: 3) also points out that, "PBL is a learning model that encourages students to learn how to learn and work together in groups to find solutions to problems".

According to Kunandar (2007: 354), "PBL is a learning model that uses real-world problems as a context for students to learn about critical thinking and problem-solving skills, and to acquire essential knowledge and concepts from learning materials. Meanwhile, according to Made (2009: 91), "PBL is a model of learning by exposing students to practical problems as a foothold in learning or in other words students learn through problems". PBL is a learning model that uses real-world problems in learning so that students are able to think critically and able to solve the problem scientifically and able to show understanding through experience in learning. PBL as a learning model has a goal to be achieved in its application. Trianto (2009: 94) argues that PBL aims to: "(1) Help students develop thinking skills and problem-solving skills, (2) help students to learn the role of authentic adults, (3) help student to become independent learners."

PBLsused in learning have stages that need to be well understood. It is intended that the PBL used is directed and can achieve the expected goals. In general, the use of PBL begins with a problem that must be solved or sought solving by students. The problem can start from the students or may be provided by the teacher. Students will focus their learning around the problem through the steps of the scientific method so as to provide hands-on experience to students to solve the problems of their direct and structured focus. Susanto (2009: 153) mentions the stages of PBL, among others: "Stage 1: provide orientation about the problem to the students, stage 2: organize students to research, stage 3: assist independent investigation in groups, and stage 4: develop and present results. "Refering from 
the opinion of experts it can be concluded that the stages in the PBL are: 1) Student orientation on the problem, 2) organizing students to study, 3) guide students to investigate, 4) develop and present the work in the form of reports from the results of the investigation, and 5) analyze and evaluate the results of the reports made. The stages carried out in this study refer to Trianto's opinion, (2009: 98) consisting of five stages: 1) Student orientation on the problem, 2) organizing students to study, 3) guiding individual and group investigations, 4) develop and present the work, and 5) analyze and evaluate the problem-solving process.

The formulation of this research problem is how to increase students' motivation in science learning by using Problem Based Learning model (PBL) in grade IV SDN 07 Belakang Balok Bukittinggi? The purpose of research to see how far the improvement of student learning motivation after learning by using Problem Based Learning model (PBL) in primary school.

\section{Method}

This research was conducted at SDN 07 Belakang Balok District Aur Birugo Tigo Baleh Bukittinggi. This study was conducted in class IV. As the subjects in this study are the authors and students of grade IV SDN 07 Belakang Balok Bukittinggi which amounted to 32 students. This research was conducted in second semester of academic year 2015/2016, from February to June 2016. This research is a classroom action research using qualitative and quantitative approach. This research is qualitative and quantitative research with research type ofclassroom action research(PTK) or classroom action research (CAR). This research begins with an initial reflection on the process of learning science in SDN 07 Belakang Balok Bukittinggi. This activity is carried out to find out the problems faced by teachers and students related to the motivation to learn is still low. The initial reflection of the research was conducted by evaluating the learning process in the classroom in the form of a discussion with the observer about the learning process that was carried out so far. Then researchers and observers formulate the problem. This research data wasthe data of observation result and motivation interview data in science learning in Class IV. Research data was collected by observation technique, questionnaire and calculation by percentage technique. Sources of data in this study were teachers and students of grade IV SDN 07 Belakang Balok Bukittinggi which amounted to 32 students. The learning process is implemented by usingProblem Based Learning (PBL) model. The stages carried out in this study refer to Trianto's opinion, (2009: 98) consisting of five stages: 1) Student orientation on the problem, 2) organizing students to learn, 3) guiding individual and group investigations, 4) develop and present the work, and 5) analyze and evaluate the problem-solving process.

\section{Result}

In the first cycle of meeting 1 , in the learning process that takes place, for example during conducting the experimental activity, the students' motivation in learning because students appear to be enthusiastic to answer teacher questions, experiment, and compete in carrying out the task given by the teacher. During this experiment conducted by the teacher if the learning activities involve experiments to make a tool or something model. With theProblem Based Learning approach theteachers conduct experiments by simply providing guidance and direction as necessary whilst students are working with their own initiative of sambal following the steps in the LKS that have been given, seen their independence emerge and this shows their motivations increases along with the process of learning in the classroom. Some students who have been known to be quiet and act as if they do not want to know if any group tasks have even begun to dare to express opinions to the forums in the group. This indicates that with Problem Based Learning approach their self-motivation to learn has emerged although not maximal. 
In conducting the research, it appears that students who are initially lazy to work and engage in learning have started to be active in learning because they themselves who carry out the experiment. Usually teachers who demonstrate in front of the class, while with the implementation of science learning with Problem Based Learning approach is students who work directly, so they are motivated to work better than his friends. This desire to be the best indicates that students have increased their motivation to learn and engage in the learning process.

In the first cycle of meeting 2, observer observation results, by carrying out this activity, teachers have been trying to motivate students to actively convey their responses. Some students are willing to express their opinions. This shows that they are already motivated to learn and want to be involved in learning activities. At the time of doing group activities, namely to experiment and solve problems through LKS distributed to each group. Not every group can be observed by teachers as a whole in conducting experimental activities. Students are willing to experiment independently and the number of students who ask teachers about how to experiment has been reduced from the first meeting. Indeed, there are still some students who come to the front of the class or raised their hands to ask the teachers about the LKS experiment steps they do not understand but they already want to experiment independently. This shows that they have increased learning motivation so that teachers no longer provide much guidance to students and students already independent in learning. Activities report on group work and discussion to analyze the results of the discussion. In the discussion activities, students in groups appear to be active in expressing their opinions. Although the class is a bit noisy during the discussion, it indicates that students are motivated to express their opinions. Teachers encourage students to be actively involved by providing questions to analyze the results of group work reports, the activities continued by giving the group the opportunity to complete the group work. The time given to complete the work of the group has not been maximized due to time constraints. Overall can be seen in the final result that the result of questionnaire in the first cycle of meeting 1 is $62 \%$ (enough), meeting 2 is $76 \%$ (good). Increased motivation questionnaire results in the first cycle is $14 \%$ with good category.

For the second cycle, improving students' motivation in learning is more visible. Good if observed from the results of questionnaires and observations made by the observer. The improvement of students' learning motivation in line with the increase of student activity in learning can also be observed by the observer by using field recording format which can be seen in the appendix. Initial activity, the greeting spoken by the teacher is answered by all students, as well as praying. When teachers hold apperception, most students answer teacher questions. When the teacher gives brief information about the material to be discussed and convey the purpose of learning, students who are usually less concentrated in receiving the delivery of learning goals from teachers have been focused in listening to the teacher's description. Opportunity to watch images, visible students serious in watching the images and video. In searching for information on erosion and abrasion through text distributed in groups, each group reads seriously the members of each focus group in reading. During group discussion, all students take a part in group work. Making the work of the group report fills the LKS, most of the group reports are correct. Thus the increase in student learning motivation has increased from previous meetings. Motivation questionnaire results show students' motivation in following science lesson. The result of questionnaire in cycle II meeting 1 is $81 \%$ (very good), meeting 2 is $87 \%$ (very good). Improved motivation in the second cycle is $6 \%$ with very good predictions. At the end of the study can be explained that the increase of motivation questionnaire results in cycle I to cycle II is $15 \%$ with good qualifications.

\section{Discussion}


The findings of the practice of science learning that have been implemented through PBL show the result that students are motivated to learn science. The teacher should be aware that in preparing students for their future, it is important to implement learning meaningfully. Because, if they gain meaningful Science learning then they will be able to plan their future for career development (Fitria; 2014).

Following the above description on the first cycle of PTK implementation, students' motivation profile in learning science in elementary school isseen increasing student's motivation to learn. Beginning with the teacher's concrete steps to deliver clear and decisive learning objectives. Which direction he wants to take. Students 'understanding of learning goals can foster students' interest to learn which in turn can improve their learning motivation. The clearer the goal to be achieved, the stronger the learning motivation of students (Sanjaya, 2009: 29). Therefore, before the learning process begins the teacher has explained in advance the goals to be achieved so that student learning motivation increases.

Furthermore, teachers have encouraged students to arouse students' interest to learn by providing good preliminary session. Students will be encouraged to learn when they have an interest in learning. Therefore, developing students' interest in learning is one of the techniques in developing learning motivation (Sanjaya, 2009: 29). One logical way to motivate students in learning is to relate learning experiences to student interests (Djiwandono, 2006: 365). Attribution of learning to student interests is very important, and therefore show that the learned knowledge is very beneficial to them. Similarly, an important learning objective is to arouse students 'curiosity about future lessons, and therefore learning will improve students' intrinsic motivation to learn the learning materials presented by the teacher (Anni, 2006: 186).

Teachers have been able to present information interestingly, and unfamiliar to students. Something of information conveyed with new techniques, with good packaging is supported by tools in the form of mediums or media that have never been known by the previous students so as to draw attention to them to learn (Yamin, 2009: 174). With an interesting learning, it will generate a sense of "want to know" the students in the learning activities that students will be motivated in learning. The intrinsic motivation to learn something can be enhanced through the use of educational learning materials, as well as the use of variations of learning methods. For example, to arouse students' interest in learning can be done by way of screening, inviting guest speakers, demonstrations, computers, simulations, role playing, radio-learning, wafting works, and others (Anni, et al., 2006: 186-187: Hamalik, 2009: 168).

In cycle II, the students' motivation increased from cycle I. Teachers have given more praise to the emergence of student activities in learning activities. Motivation will grow when students feel appreciated. In learning, praise can be used as a motivational tool. Because students are also human beings, so he also likes to be praised. Because the praise raises a sense of satisfaction and pleasure (Sanjaya, 2009: 30; Hamalik, 2009: 167). However, praise must be in accordance with the work of students. Do not over praise because it will seem artificial. Good praise is the praise that comes out from the heart of a teacher naturally in order to reward students for their hard work in learning (Djamarah and Zain, 2006: 152).

Furthermore, in carrying out the assessment, in cycle II, the teacher also has given a fair assessment and appropriate rewards for students. This only increases students' motivation to learn. Many students are learning because they want to get good grades. For some student, grades can be a powerful motivation to learn. Therefore, the assessment should be done immediately so that students as soon as possible know the results of their work. Assessment should be done objectively according to the ability of each student (Sanjaya, 2009: 31). It should be emphasized that the drive or driving force is learning, sourced from appreciation or a need, but that need can actually be affected by other activities, not necessarily through learning. The motivation to learn always stems from an individual's 
own needs, although others play a role in generating that motivation, which is typical in extrinsic motivation is not the presence or absence of outside influences, but whether the needs to be fulfilled can basically only be met by other. Continuous assessment will encourage students to learn, because each child has a tendency to achieve good results. In addition, the students always get challenges and problems to be faced and solved, thus encouraging them to study more thoroughly and thoroughly (Hamalik, 2009: 168).

Students need rewards. The rewards can be done by giving positive comments. After the student finishes a task, you should comment immediately, for example by writing "good" or "continue your work" and so on. A student learns because driven by his mental strength, the mental power of desire, attention, will, or ideals, and mental strength, can be classified as low and high. Motivation is seen as a mental impulse that moves and directs human behavior, including learning behavior. In motivation depends on the desire to activate, move, channel and direct attitude and behavior learn. There are at least two main components in motivation, namely need, encouragement and purpose. Students who are motivated, he will make reactions that directed himself to efforts to achieve goals and will reduce the tension generated by the energy inside him. In other words, themotivation tolead itself to the reactions reaches the goal, for example to be appreciated and acknowledged by others. This is in accordance with the expert opinion that positive comments can improve students' learning motivation (Sanjaya, 2009: 21). The awards are very effective in motivating the students to do the tasks, both tasks that must be done immediately, as well as ongoing tasks (Prayitno, 1989: 17). Conversely, giving less motivation is less motivational in learning. Even cause a bad psychological effects.

\section{Conclusions and Suggestions}

In accordance with the purpose of research that has been determined that is to improve students' learning motivation science using Problem Based Learning modelin Class IV SDN 07 Belakang Balok Bukittinggi, it can be drawn a conclusion as follows: PBL model can improve student motivation in science learning by using model Problem Based Learning (PBL) in grade IV SDN 07 Belakang Balok Bukittinggi. PBL model can improve student learning outcomes in science learning by using Problem Based Learning model (PBL) in grade IV SDN 07 Belakang Balok Bukittinggi.

The use of problem based learning model in class IV SDN 07 Belakang Balok Bukittinggi, very effective to improve learning motivation of science learning. Conclusions drawn certainly have implications in the learning process and also further studies, in connection with the above implications are as follows: Implications for the increase in student learning motivation in learning science by using problem based learning model. Students' motivation in the learning process is very necessary, learning will be meaningful if students engage with various activities in finding and finding facts and build their own concepts. During this time the learning is generally still centered on the teacher. Students as listener and teacher information recording. This causes students to be inactive in the learning process. Teachers in the learning process using problem based learning model acts as a facilitator.The teacher guides the students in each activity performed. Learning science by using problem-based learning model proved to improve student's learning motivation. So the problembased learning model can be used by teachers in schools that want to improve students' learning motivation.Researcher give some suggestion in implementation of learning with problem based learning model based on result of research which have been implemented that is as follows: For teacher, suggest that in learning process, teacher should involve student with various learning activity. Learning by using problem-based learning model can be used as an alternative in learning science to improve student's learning motivation. 


\section{Acknowledgment}

We would like to thank you to Prof.Prof. Dr.Dr. Ardipal, M.Pd and Dr. Yanti Fitria, M.Pd as a supervisor whose are full of sincerity and patience provides valuable guidance and motivation in completing this article.

\section{References}

Anas, S. (2009). Pengantar evaluasi pendidikan. Jakarta: PT. Grafindo Persada.

Depdiknas. (2004). Kurikulum pendidikan. Jakarta: Badan Standar Nasional Pendidikan.

Depdiknas. (2006). Kurikulum tingkat satuan pendidikan. Jakarta: Badan Standar Nasional Pendidikan.

Djamarah, S. (2006). Pembelajaran IPS di sekolah dasar. Bandung: Remaja Rosda Karya.

Djiwandono. (2006). Pembelajaran abad 21. Jakarta: Gema Persada.

Fitria, Y. (2014). Pedagogi. Jurnal Ilmiah Ilmu Pendidikan. 82-87.

Fitria, Y. (2017). Pembelajaran literasi sains untuk level dasar, Himpunan Dosen PGSD. 30-40.

Fitria, Y. (2017). Efektivitas capaian kompetensi belajar siswa dalam pembelajaran sains di sekolah dasar. Jurnal Inovasi Pendidikan dan Pembelajaran Sekolah Dasar, 34-42.

Hamalik, O. (2008). Proses belajar mengajar. Jakarta: BumiAksara.

Hamalik, O. (2009). Proses belajar mengajar. Jakarta: BumiAksara.

Kunandar. (2007). Guru professional implementasi kurikulum tingkat satuan pendidikan (KTSP) dan sukses dalam sertifikasi guru. Jakarta: PT. Grafindo Persada.

Prayitno. (1989). Learning in progress. Bandung: Remaja Rosda Karya.

Ronis, D. (2009). Problem based learning for math and science: integrating inquiry and the internet. New York: Skylight Professional Development.

Sanjaya, W. (2008). Strategi pembelajaran berorientasi standar proses pendidikan. Jakarta: Kencana Prenada Media Group.

Sanjaya, W. (2009). Strategi pembelajaran berorientasi standar proses pendidikan. Jakarta: Kencana Prenada Media Group.

Samatowa, U. (2011). Sains dalam sekolah dasar. http://id.wikipedia.org/wiki/SCIENCE. Diakses tanggal 10 Maret 2015.

Siregar, E. (2007). Teori belajar dan pembelajaran. Jakarta: FIP UNJ.

Suryabrata, S. (2009). Metodologi penelitian. Jakarta: Rajawali Pers.

Suyitno, dkk. (2008). Perencanaan pembelajaran. Jakarta: FT UNJ.

Trianto.(2007). Model-model Pembelajaran inovatif berorientasi konstruktvistik. Jakarta: Prestasi Pustaka.

Wena, M. (2009). Strategi pembelajaran inovatif kontemporer. Jakarta: Earth Literacy.

Yamin, M. (2009). Profesionalisme guru dan implementasi KTSP. Jakarta: Gaung Persada Press. 